\title{
CD318/CUB-domain-containing protein 1 expression on cord blood hematopoietic progenitors
}

\author{
HIROMI TAKEDA $^{1}$, YOSHIHIRO FUJIMORI ${ }^{1,2}$, SHUNRO KAI ${ }^{3}$, HIROYASU OGAWA $^{1}$ and TAKASHI NAKANO ${ }^{2,4}$ \\ ${ }^{1}$ Laboratory of Cell Transplantation, Institute for Advanced Medical Sciences, ${ }^{2}$ Cancer Center, \\ ${ }^{3}$ Department of Transfusion Medicine, ${ }^{4}$ Division of Respiratory Medicine, Department of Internal Medicine, \\ Hyogo College of Medicine, Hyogo 663-8501, Japan
}

Received January 20, 2010; Accepted March 19, 2010

DOI: $10.3892 /$ etm_00000078

\begin{abstract}
CUB-domain-containing protein 1 (CDCP1)/ CD318 is a single transmembrane molecule highly expressed in colorectal cancer and leukemia. It has also been shown to be expressed in hematopoietic progenitor cells. In this study, we analyzed the expression of CD318 on cord blood hematopoietic stem and progenitor cells. Cord blood mononuclear cells were depleted of mature blood cell linage (Lin)-positive cells and then Lin-negative cells were sorted by flow cytometry based on the expression of CD34 and CD318. Analysis of sorted cells by colony-forming assay showed that $\mathrm{CD} 34{ }^{+} \mathrm{CD} 318^{+}$cells produced more mixed colony forming units and erythroid burst forming unit-derived colonies than CD $34{ }^{+} \mathrm{CD} 318-$ cells. These colonies were also produced by $\mathrm{CD} 34^{-} \mathrm{CD} 318^{+}$and $\mathrm{CD} 34^{-} \mathrm{CD} 318^{-}$cells, but were generally fewer in number. When sorted cells were cultured on a monolayer of human mesenchymal stem cells, CD $34{ }^{+} \mathrm{CD} 318^{+}$ cells proliferated more abundantly than $\mathrm{CD} 34^{+} \mathrm{CD} 318^{-}$cells, while CD34-CD318+ and CD34-CD318- cells failed to proliferate. Transplantation of $\mathrm{CD} 34{ }^{+} \mathrm{CD} 318^{+}$cells into non-obese diabetic/severe combined immunodeficient disease (NOD/ SCID) mice resulted in efficient reconstitution of human cells, indicating that $\mathrm{CD} 34^{+} \mathrm{CD} 318^{+}$cells possess strong SCID-repopulating cell activity. These findings suggest that the co-expression of CD34 and CD318 identifies the immature character of hematopoietic stem cells.
\end{abstract}

\section{Introduction}

CUB-domain-containing protein 1 (CDCP1), also known as CD318, was first identified as the product of a gene preferentially expressed in colon cancer cells (1). CDCP1/CD318 is a

Correspondence to: Dr Yoshihiro Fujimori, Laboratory of Cell Transplantation, Institute for Advanced Medical Sciences, Hyogo College of Medicine, 1-1 Mukogawa-cho, Nishinomiya, Hyogo 663-8501, Japan

E-mail: fuji-y@hyo-med.ac.jp

Key words: hematopoietic stem cells, hematopoiesis, CD318, CD34 type I transmembrane protein containing three CUB (complement protein subcomponents $\mathrm{C} 1 / \mathrm{r}$, urchin embryonic growth factor and bone morphogenic protein 1) domains within the extracellular region and a hexalysine stretch within the cytoplasmic region (1). CD318/CDCP1 are possibly involved in cell adhesion or extracellular matrix interaction $(1,2)$, and CD318 expression levels are correlated with the metastatic ability of carcinoma cells (3). CDCP1 mRNA was also detected in lung, breast and gastric cancers and in the erythroleukemia cell line K562 (1-4). In addition, expression of CD318 has been reported in hematopoietic stem, mesenchymal stem and neuronal progenitor cells (5).

Human hemaptopoietic stem and progenitor cells (HSCs/ HPCs) can differentiate into many types of mature blood cells including erythrocytes, granulocytes and thrombocytes (6). Human $\mathrm{CD} 4^{+}$cells include several classes of HSCs/HPCs, such as relatively mature in vitro colony forming cells (CFCs), relatively immature long-term culture initiating cells (LTC-IC) and immature transplantable SCID-repopulating cells (SRCs), that can engraft in non-obese diabetic/severe combined immunodeficient disease (NOD/SCID) mice (7-9). Subpopulations of $\mathrm{CD} 34^{+}$cells, such as $\mathrm{CD} 34{ }^{+} \mathrm{CD} 38^{-}$and $\mathrm{CD} 34^{+} \mathrm{CD} 133^{+}$cells, have been reported to be rich in immature hematopoietic cells including SRCs $(10,11)$.

In hematopoetic cells in the bone marrow (BM) and cord blood (CB), CD318 is expressed on $\mathrm{CD} 4^{+}$cells, but not on mature hematopoietic cells (5). In leukemia, CD318 is predominantly expressed on $\mathrm{CD} 34^{+} \mathrm{CD} 133^{+}$myeloid leukemic blasts. The transplantation of purified CD $318^{+}$cells into NOD/ SCID mice results in the engraftment of human cells with multi-lineage differentiation potential (12).

In the present study, we analyzed the expression and hematopoietic activity of CD318 on CB hematopoietic cells in relation to $\mathrm{CD} 34$ expression. We found that $\mathrm{CD} 34^{+} \mathrm{CD} 318^{+}$ cells were rich in CFCs, proliferated well on a monolayer of mesenchymal stem cells and showed high SRC activity. We conclude that CD318 expression on $\mathrm{CD}^{+} 4^{+}$cells identifies immature hematopoietic stem cells.

\section{Materials and methods}

Cytokines. Recombinant human (rh)-interleukin (IL)-3, rh-stem cell factor (SCF), rh-granulocyte colony-stimulating 
factor (G-CSF), rh-granulocyte/macrophage (GM)-CSF, rh-thrombopoietin (TPO) and rh-erythropoietin (Epo) were a generous gift from the Kirin Brewery Co. Ltd. (Tokyo, Japan). Flt3 ligand (FL) was purchased from R\&D Systems (Minneapolis, MN).

Mice. Eight-week-old female NOD/shi/SCID mice were purchased from Clea Japan (Tokyo, Japan). The mice were maintained on racks under specific pathogen-free conditions with a laminar air flow and were supplied with sterile food and drinking water.

Isolation of lineage-negative cord blood cells. Umbilical CB was obtained from normal full-term deliveries after obtaining consent of the mothers. This study was approved by the institutional review board. Mononuclear cells (MCs) were separated by density gradient centrifugation using FicollPaque (GE Healthcare, Buckinghamshire, UK). The MCs were subjected to depletion of lineage-positive cells using the automated magnetic cell sorter (autoMACS) system (Miltenyi Biotec Inc., Auburn, CA) and the Lineage Cell Depletion kit, which included biotinylated antibodies to lineage-specific antigens (CD2, CD3, CD11b, CD14, CD15, CD16, CD19, CD56, CD123 and CD235a) and anti-biotin magnetic microbeads (Miltenyi Biotec Inc.). The lineage-negative CB cells were frozen in $\alpha$-medium supplemented with $10 \%$ dimethylsulfoxide and $12 \%$ hydroxyethyl starch (CP-1 cryoprotectant; Kyokuto Pharmaceutical Co., Tokyo, Japan) and $8 \%$ human serum albumin in a $-80^{\circ} \mathrm{C}$ freezer.

Flow cytometric analysis and cell sorting. Lineage-negative cells were stained with fluorescein isothiocyanate (FITC)conjugated anti-CD34 monoclonal antibodies (Beckman Coulter, Miami, FL), phycoerythrin (PE)-conjugated antiCD318/CDCP1 antibodies (clone CUB1; BioLegend, San Diego, CA) and phycoerythrin-cyanin 7 (PC7)-conjugated anti-CD45 antibody (Beckman Coulter) at $4^{\circ} \mathrm{C}$ for $30 \mathrm{~min}$. The cells were also stained with 7-amino-actinomycin D (7-AAD) (Beckman Coulter) to exclude dead cells, in which 7-AAD-positive cells were gated out. Immunofluorescence analysis and sorting were performed using FACSAria (Becton-Dickinson). Appropriate isotype-matched antibodies were used as a control in all of the experiments.

Colony-forming cell assay. Colony-forming cell (CFC) assays were performed in 35-mm Petri dishes (Becton-Dickinson) by incubating the cells in semisolid $\alpha$-medium containing $0.8 \%$ methylcellulose (Shinetsu Chemicals Co., Tokyo, Japan), 30\% fetal calf serum (Gibco BRL, Grand Island, NY), $1 \%$ bovine serum albumin, $10^{-4} \mathrm{M}$ 2-mercaptoethanol (2-ME; Wako Pure Chemicals, Osaka, Japan), $2 \mathrm{mM}$ l-glutamine (Sigma), $10 \mathrm{ng} / \mathrm{ml} \mathrm{IL-3,} 20 \mathrm{ng} / \mathrm{ml} \mathrm{SCF}, 10 \mathrm{ng} / \mathrm{ml}$ G-CSF, $10 \mathrm{ng} / \mathrm{ml}$ GM-CSF and $2 \mathrm{U} / \mathrm{ml}$ Epo (Kirin Brewery) for 14 days at $37^{\circ} \mathrm{C}$ in a humidified atmosphere flushed with $5 \% \mathrm{CO}_{2}$ in air (13-15). The colony-forming units (CFU)-GM, CFU-Mix and burst-forming units-erythroid (BFU-E) were identified by the ability to form granulocyte/macrophage (GM) colonies, mixed erythroid and myeloid (Mix) colonies and erythroid burst colonies, respectively, as described previously (13-15).
Co-culture of cord blood cells with human mesenchymal stem cells (MSCs) in the presence of cytokines. MSCs, established from normal BM cells, were purchased from BioWhittaker, Inc. (San Diego, CA) and maintained as previously described (16). Cells $\left(1 \times 10^{3}\right.$ cells/well in a 12 -well plate) were seeded on a layer of MSCs in $1 \mathrm{ml}$ of serum-free medium, StemPro34 supplemented with StemPro-34 nutrient supplement (both from Gibco BRL), $2 \mathrm{mM}$ glutamine and penicillin/streptomycin in the presence of $100 \mathrm{ng} / \mathrm{ml} \mathrm{SCF}, 100 \mathrm{ng} / \mathrm{ml} \mathrm{TPO}$ and $100 \mathrm{ng} / \mathrm{ml} \mathrm{FL}$. After 7 and 14 days of culture, cells were harvested and counted.

SCID-repopulating cell (SRC) assay. Cells $\left(1 \times 10^{4}\right)$ were injected through the tail vein into 10 -week-old NOD/shi/SCID mice sublethally irradiated (3 Gy X-ray). The mice were intraperitoneally injected with anti-asialo GM1 antibody (Wako Pure Chemical) to reduce the natural killer cell activity (17). The mice were sacrificed 8 weeks after the transplantation and analyzed for human DNA in BM cells as previously described $(16,18)$. Briefly, DNA was extracted from BM cells using a SepaGene extraction kit (Sanko Pure Chemical Co., Tokyo, Japan) and analyzed for the human-specific DNA $17 \alpha$-satellite gene by quantitative real-time PCR (19). The primers used were sense 5'-ACGGGATAACTGCACCTAAC-3', and antisense 5'-CCATAGGAGGGTTCAACTCT-3'. All experimental procedures were performed according to the Guidelines for the Care and Use of Animals approved by the Animal Committee of Hyogo College of Medicine.

Statistical analysis. Data are presented as the mean \pm standard error (SE). The Student's t-test was used. P-values of $<0.05$ were accepted as significant.

\section{Results}

Expression of CD318 on hematopoietic progenitors. We characterized the expression of CD318 in cord blood cells by flow cytometry. Lineage-negative cord blood cells were gated in the blast/lymphocyte region (R1) (Fig. 1A), and then CD45 ${ }^{\mathrm{dim}+}$ cells with $\mathrm{CD}^{+} 4^{+}$(R2) and CD34- (R3) were gated (Fig. 1B). The expression of CD318 on $\mathrm{CD}^{+} 4^{+}$cells was $\sim 70 \%$ (Fig. 1C) and that of $\mathrm{CD} 318$ on CD34- cells was $\sim 60 \%$ (Fig. 1D). $\mathrm{CD}^{2}{ }^{+} \mathrm{CD} 318^{+}$(R5), CD34 ${ }^{+} \mathrm{CD} 318^{-}$(R4), CD34-CD318+ (R7) and CD34-CD318-(R6) cells were individually sorted for the following functional analyses.

Colony formation of sorted cells by means of CD34 and $C D 318$. We analyzed sorted cells by the hematopoietic colony forming assay (Fig. 2). $\mathrm{CD} 34^{+} \mathrm{CD} 318^{+}$and $\mathrm{CD} 34^{+} \mathrm{CD} 318$ cells formed colonies of CFU-Mix, BFU-E and CFU-GM. CFU-Mix and BFU-E colonies in the $\mathrm{CD} 34^{+} \mathrm{CD} 318^{+}$ cells were significantly more in number than those in the CD34+CD318- cells $(\mathrm{P}<0.05)$. CD34-CD318+ and CD34CD318- cells also formed these colonies, but were generally fewer in number except for BFU-E in $\mathrm{CD} 34^{-} \mathrm{CD} 318^{+}$cells. In fact, CD34-CD318+ cells formed more BFU-E colonies than CD34-CD318- cells $(\mathrm{P}<0.05)$.

Proliferative capacity of sorted cells in co-culture with MSCs. Sorted cells were cultured on a layer of MSCs in the 

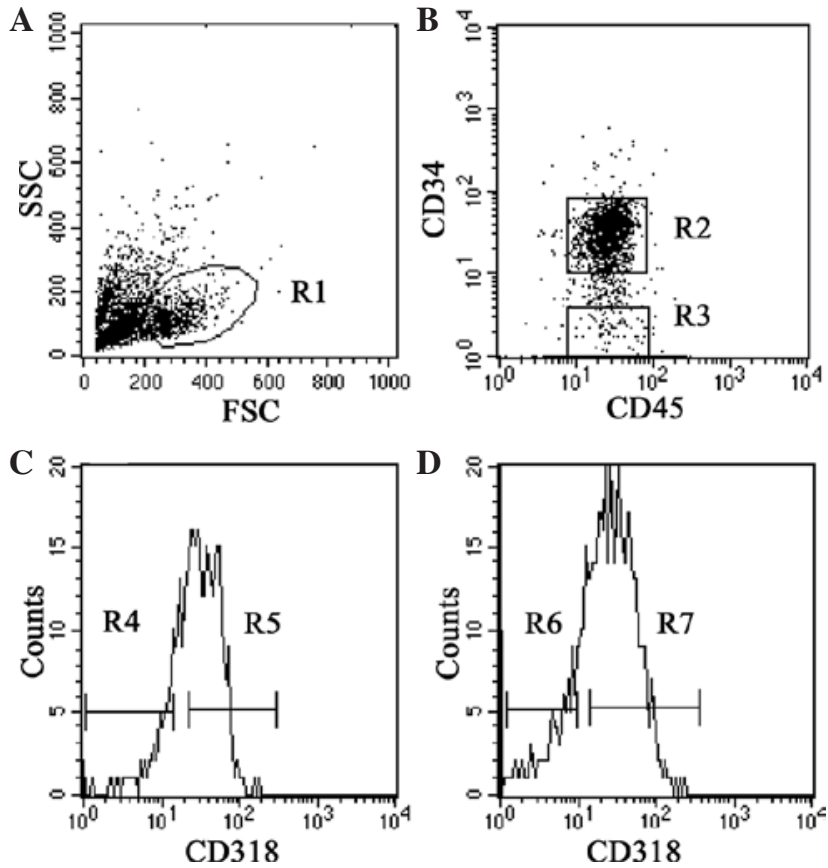

Figure 1. Expression of $\mathrm{CD} 318 / \mathrm{CDCP} 1$ on hematopoietic progenitors. (A) Blast/lymphocyte gate (R1) on forward scatter (FSC) and side scatter (SSC) for the identification of $\mathrm{CD} 34^{+}$cells. (B) $\mathrm{CD} 45^{\mathrm{dim}+} \mathrm{CD} 34^{+}(\mathrm{R} 2)$ and ${ }^{C D} 45^{\text {dim+ }}{ }^{-}$D34- $(R 3)$ cells after being gated in R1. (C) Sorting of CD318 (R5) and CD318- (R4) cells was performed after being gated in the CD34+ (R2) fraction. (D) Sorting of CD318+ (R7) and CD318- (R6) cells was performed after being gated in the CD34- (R3) fraction.

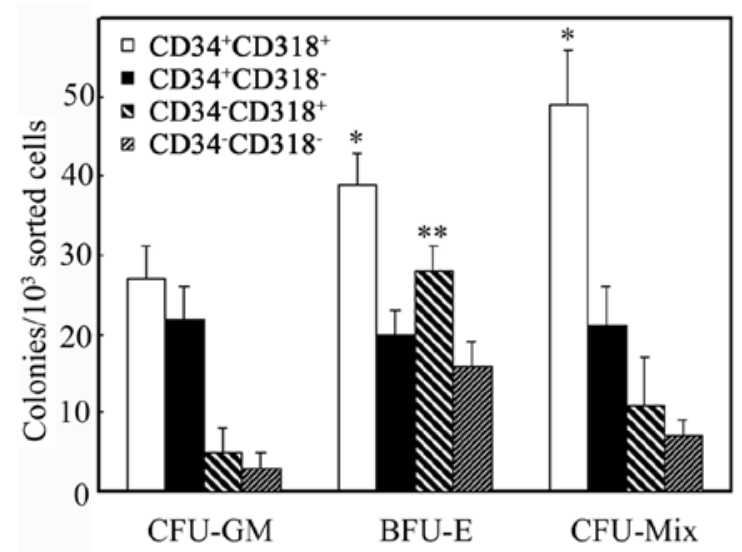

Figure 2. Colony formation of the sorted cells by means of CD34 and CD318. Sorted cell fractions $\left(1 \times 10^{3} \mathrm{CD} 34^{+}\right.$and $1 \times 10^{4} \mathrm{CD} 34-$ cells) were analyzed by the hematopoietic colony forming assay to determine CFU-GM, BFU-E and CFU-Mix colonies. Data are the mean \pm SE per $1 \times 10^{3}$ sorted cells of three separate experiments. ${ }^{*} \mathrm{P}<0.05$ in comparison to $\mathrm{CD} 34^{+} \mathrm{CD} 318$ - cells. ${ }^{* *} \mathrm{P}<0.05$ in comparison to $\mathrm{CD} 34{ }^{-\mathrm{CD}} 318^{-}$cells.

presence of SCF, TPO and FL. As shown in Fig. 3, proliferation of the total viable cells was noted when $\mathrm{CD} 34^{+} \mathrm{CD} 318^{+}$ cells were cultured on MSCs. When $\mathrm{CD} 34^{+} \mathrm{CD} 318$ cells were cultured, proliferation was significantly lower than that of $\mathrm{CD}^{2}{ }^{+} \mathrm{CD} 318^{+}$cells $(\mathrm{P}<0.001)$. No proliferation was observed for $\mathrm{CD}^{-} 4^{-\mathrm{CD}} 318^{+}$and $\mathrm{CD} 34-\mathrm{CD} 318^{-}$cells. These results suggest that $\mathrm{CD} 34^{+} \mathrm{CD} 318^{+}$cells have the highest proliferative potential.

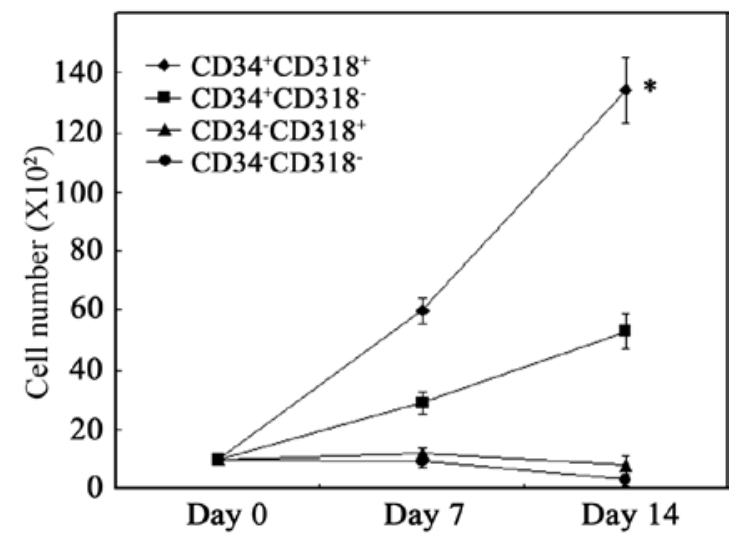

Figure 3. Proliferative capacity of the sorted cell fractions in co-culture with MSCs. Cells $\left(1 \times 10^{3}\right)$ were co-cultured with MSCs in the presence of SCF, TPO and FL. On days 7 and 14, the cells were collected and analyzed for viable cells. Data are the mean $\pm \mathrm{SE}$ of three separate experiments. ${ }^{\mathrm{P}} \mathrm{P}<0.001$ in comparison to $\mathrm{CD} 34^{+} \mathrm{CD} 318$ cells.

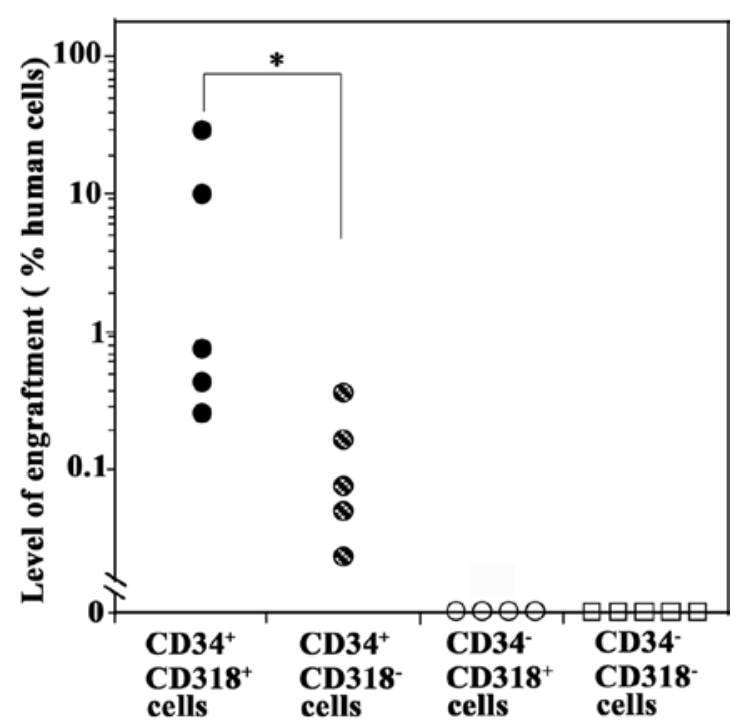

Figure 4. Analysis of the engraftment of SCID-repopulating cells of the sorted cell fractions. Cells $\left(1 \times 10^{4}\right)$ were transplanted into sublethally irradiated NOD/SCID mice and 8 weeks later the engraftment level in the bone marrow was analyzed by real-time PCR analysis of the human-specific DNA $17 \alpha$-satellite gene. ${ }^{*} \mathrm{P}<0.05$ in comparison to $\mathrm{CD} 34{ }^{+} \mathrm{CD} 318$ - cells.

SCID-repopulating cell assays of the sorted cells. We next performed SRC assays by transplanting each sorted cell fraction into NOD/SCID mice through the tail vein. Eight weeks later, the mice were analyzed for human hematopoietic cells in the BM by real-time PCR analysis of the human-specific DNA $17 \alpha$-satellite gene.

All five mice transplanted with primary $\mathrm{CD} 34^{+} \mathrm{CD} 318^{+}$ cells were positive for the human DNA, indicating that primary $\mathrm{CB}$ CD $34^{+} \mathrm{CD} 318^{+}$cells contained SCID-repopulating cells (SRCs) (Fig. 4). CD34+CD318- cells were also engrafted, but to a significantly lower degree than the $\mathrm{CD} 34^{+} \mathrm{CD} 318^{+}$cells $(\mathrm{P}<0.05)$. By contrast, mice transplanted with $\mathrm{CD} 34-\mathrm{CD} 318^{+}$ or CD34-CD318 cells were negative for the human DNA, indicating the absence of the SCID-repopulating capacity. 
These results showed that $\mathrm{CD} 34^{+} \mathrm{CD} 318^{+}$cells had the highest SRC activity.

\section{Discussion}

CD318/CDCP1 was first found to be expressed in colon cancer cells and then in breast, lung and other types of cancer cells $(1,2)$. Expression of CD318 has also been reported in cells phenotypically identical to hematopoietic stem/progenitor cells, MSCs and neural progenitor cells (5). Human CD318+ cells transplanted into NOD/SCID mice resulted in the engraftment of human cells showing SRC activity (12). In the present study, we analyzed the expression and hematopoietic activity of CD318 on hematopoietic cells in relation to CD34 expression.

We confirmed that $\mathrm{CD} 318$ was expressed on $\mathrm{CD}^{+} 4^{+}$ cells. We found that $\mathrm{CD} 34{ }^{+} \mathrm{CD} 318^{+}$cells were rich in $\mathrm{CFCs}$, including CFU-Mix and BFU-E, and exhibited more proliferative activity on adherent cells than on $\mathrm{CD} 344^{+} \mathrm{CD} 318-$ cells. Notably, the $\mathrm{CD} 34{ }^{+} \mathrm{CD} 318^{+}$cells showed high SRC activity. These findings suggest that $\mathrm{CD} 34^{+} \mathrm{CD} 318^{+}$cells were rich in hematopoietic progenitors and also rich in immature HSCs.

It has been reported that CD34- cells, like CD34+ cells, contain hematopoietic stem cells (20). In this study, we found that $\mathrm{CD} 38^{+}$cells were present in the $\mathrm{CD} 34^{-}$cell fraction. These CD34-CD318+ cells had the capacity to form hematopoietic colonies, especially erythroid (BFU-E) colonies. However, CD34-CD318+ cells did not proliferate on adherent cell layers and contained no SRCs. Similarly, CD318- cells in the CD34fraction contained colony-forming cells, but not SRCs.

CD318/CDCP1 has been reported to play a role in cell-cell and cell-matrix adhesion (3). In epithelial tissues, CD318/ CDCP1/Trask is phosphorylated by Src kinases to undergo mitosis or shedding when epithelial cells disengage from the tissue framework $(21,22)$. In the BM, hematopoietic cells attach to and are nursed by the cells of the hematopoietic niche and detach from the niche to circulate in the peripheral blood. It is intriguing to speculate that circulating HPCs/HSCs express high levels of CD318. It has been known that Src is involved in hematopoiesis (23). As CD318-reactive monoclonal antibody CUB1 augments erythroid colony formation (5), it is possible that the phosphorylation of CD318/CDCP1 by Src kinase may affect hematopoiesis.

Our study showed that CD318 expression on CD34+ cells identifies immature hematopoietic stem cells. This result provides a basis for effective hematopoietic stem cell therapy for various diseases including malignancy. Further studies are warranted to clarify whether CD318/CDCP1 is directly associated with the hematopoietic stem cell function.

\section{Acknowledgements}

We are grateful to Ms. Yumiko Fujita, Ms. Kumi Futawaka and Ms. Hatsuka Seki for the excellent technical assistance. This study was supported by a grant from Hyogo College of Medicine, and a research grant for the 'High-Tech Research Center' Project for Private Universities from the Ministry of Education, Culture, Sports, Science and Technology of Japan.

\section{References}

1. Scherl-Mostageer M, Sommergruber W, Abseher R, Hauptmann R, Ambros P and Schweifer N: Identification of a novel gene, CDCP1, overexpressed in human colorectal cancer. Oncogene 20: 4402-4408, 2001.

2. Bhatt AS, Erdjument-Bromage H, Tempst P, Craik CS and Moasser MM: Adhesion signaling by a novel mitotic substrate of src kinases. Oncogene 24: 5333-5343, 2005.

3. Uekita T, Tanaka M, Takigahira M, Miyazawa Y, Nakanishi Y, Kanai Y, Yanagihara K and Sakai R: CUB-domain-containing protein 1 regulates peritoneal dissemination of gastric scirrhous carcinoma. Am J Pathol 172: 1729-1739, 2008.

4. Ikeda JI, Morii E, Kimura H, Tomita Y, Takakuwa T, Hasegawa JI, Kim YK, Miyoshi Y, Noguchi S, Nishida T and Aozasa K: Epigenetic regulation of the expression of the novel stem cell marker CDCP1 in cancer cells. J Pathol 210: 75-84, 2006.

5. Bühring HJ, Kuçi S, Conze T, Rathke G, Bartolović K, Grünebach F, Scherl-Mostageer M, Brümmendorf TH, Schweifer N and Lammers R: CDCP1 identifies a broad spectrum of normal and malignant stem/progenitor cell subsets of hematopoietic and nonhematopoietic origin. Stem Cells 22: 334-343, 2004.

6. Dorshkind K: Regulation of hematopoiesis by bone marrow stromal cells and their products. Annu Rev Immunol 8: 111-137, 1990.

7. Baines P, Mayani H, Bains M, Fisher J, Hoy T and Jacobs A: Enrichment of CD34 (My10)-positive myeloid and erythroid progenitors from human marrow and their growth in cultures supplemented with recombinant human granulocyte-macrophage colony-stimulating factor. Exp Hematol 16: 785-978, 1988.

8. Gartner S and Kaplan HS: Long-term culture of human bone marrow cells. Proc Natl Acad Sci USA 77: 4756-4759, 1980.

9. Larochelle A, Vormoor J, Hanenberg H, Wang JC, Bhatia M, Lapidot T, Moritz T, Murdoch B, Xiao XL, Kato I, Williams DA and Dick JE: Identification of primitive human hematopoietic cells capable of repopulating NOD/SCID mouse bone marrow: implications for gene therapy. Nat Med 2: 1329-1337, 1996.

10. Bhatia M, Wang JC, Kapp U, Bonnet D and Dick JE: Purification of primitive human hematopoietic cells capable of repopulating immune-deficient mice. Proc Natl Acad Sci USA 94: 5320-5325, 1997.

11. De Wynter EA, Buck D, Hart C, Heywood R, Coutinho LH, Clayton A, Rafferty JA, Burt D, Guenechea G, Bueren JA, Gagen D, Fairbairn LJ, Lord BI and Testa NG: CD34 ${ }^{+} \mathrm{AC} 133^{+}$ cells isolated from cord blood are highly enriched in long-term culture-initiating cells, NOD/SCID-repopulating cells and dendritic cell progenitors. Stem Cells 16: 387-396, 1998.

12. Conze T, Lammers R, Kuci S, Scherl-Mostageer M, Schweifer N, Kanz L and Buhring HJ: CDCP1 is a novel marker for hematopoietic stem cells. Ann NY Acad Sci 996: 222-226, 2003.

13. Hara H, Kai S, Fushimi M, Taniwaki S, Okamoto T, Ohe Y, Fujita S, Noguchi K, Senba M, Hamano T, Kanamaru A and Nagai K: Pluripotent hemopoietic precursors in vitro (CFU-MIX) in aplastic anemia. Exp Hematol 8: 1165-1171, 1980.

14. Fujimori Y, Hara H and Nagai K: Effect of lymphokine-activated killer cell fraction on the development of human hematopoietic progenitor cells. Cancer Res 48: 534-538, 1988.

15. Fujimori Y, Ogawa M, Clark SC and Dover GJ: Serum-free culture of enriched hematopoietic progenitors reflects physiologic levels of fetal hemoglobin biosynthesis. Blood 75: 1718-1722, 1990.

16. Nishioka K, Fujimori Y, Hashimoto-Tamaoki T, Kai S, Qiu H, Kobayashi N, Tanaka N, Westerman KA, Leboulch P and Hara $\mathrm{H}$ : Immortalization of bone marrow-derived human mesenchymal stem cells by removable simian virus $40 \mathrm{~T}$ antigen gene: Analysis of the ability to support expansion of cord blood hematopoietic progenitor cells. Int J Oncol 23: 925-932, 2003.

17. Yoshino H, Ueda T, Kawahata M, Kobayashi K, Ebihara Y, Manabe A, Tanaka R, Ito M, Asano S, Nakahata T and Tsuji K: Natural killer cell depletion by anti-asialo GM1 antiserum treatment enhances human hematopoietic stem cell engraftment in NOD/Shi-scid mice. Bone Marrow Transplant 26: 1211-1216, 2000. 
18. Qiu H, Fujimori Y, Kai S, Fujibayashi Y, Nishioka K and Hara $\mathrm{H}$ : Establishment of mouse embryonic fibroblast cell lines that promote ex vivo expansion of human cord blood CD34 ${ }^{+}$ hematopoietic progenitors. J Hematother Stem Cell Res 12: 39-46, 2003.

19. Becker M, Nitsche A, Neumann C, Aumann J, Junghahn I and Fichtner I: Sensitive PCR method for the detection and real-time quantification of human cells in xenotransplantation systems. $\mathrm{Br}$ J Cancer 87: 1328-1335, 2002.

20. Bhatia M, Bonnet D, Murdoch B, Gan OI and Dick JE: A newly discovered class of human hematopoietic cells with SCIDrepopulating activity. Nat Med 4: 1038-1045, 1998.
21. Wong CH, Baehner FL, Spassov DS, Ahuja D, Wang D, Hann B, Blair J, Shokat K, Welm AL and Moasser MM: Phosphorylation of the SRC epithelial substrate Trask is tightly regulated in normal epithelia but widespread in many human epithelial cancers. Clin Cancer Res 15: 2311-2322, 2009.

22. Spassov DS, Baehner FL, Wong $\mathrm{CH}$, McDonough $\mathrm{S}$ and Moasser MM: The transmembrane src substrate Trask is an epithelial protein that signals during anchorage deprivation. Am J Pathol 174: 1756-1765, 2009.

23. Rane SG and Reddy EP: JAKs, STATs and Src kinases in hematopoiesis. Oncogene 21: 3334-3358, 2002. 